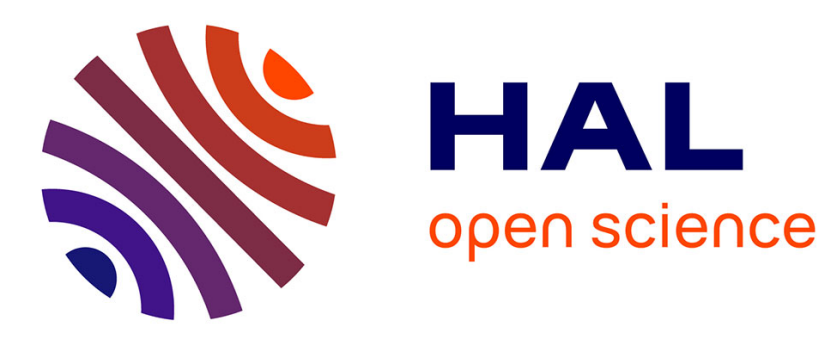

\title{
Evaluating Multi-dimensional Risk for Digital Services in Smart Cities
}

\author{
Syed Ziaul Mustafa, Arpan Kumar Kar
}

\section{To cite this version:}

Syed Ziaul Mustafa, Arpan Kumar Kar. Evaluating Multi-dimensional Risk for Digital Services in Smart Cities. 16th Conference on e-Business, e-Services and e-Society (I3E), Nov 2017, Delhi, India. pp.23-32, 10.1007/978-3-319-68557-1_3 . hal-01768499

\section{HAL Id: hal-01768499 \\ https://hal.inria.fr/hal-01768499}

Submitted on 17 Apr 2018

HAL is a multi-disciplinary open access archive for the deposit and dissemination of scientific research documents, whether they are published or not. The documents may come from teaching and research institutions in France or abroad, or from public or private research centers.
L'archive ouverte pluridisciplinaire HAL, est destinée au dépôt et à la diffusion de documents scientifiques de niveau recherche, publiés ou non, émanant des établissements d'enseignement et de recherche français ou étrangers, des laboratoires publics ou privés. 


\title{
Evaluating Multi-dimensional Risk for Digital Services in Smart Cities
}

\author{
Syed Ziaul Mustafa ${ }^{1}$ and Arpan Kumar Kar ${ }^{2}$ \\ ${ }^{1}$ Center of Excellence in Cyber Systems and Information Assurance (CoE-CSIA), Indian Insti- \\ tute of Technology Delhi, New Delhi - 110016, INDIA \\ ${ }^{2}$ Department of Management Studies, Indian Institute of Technology Delhi, New Delhi - \\ 110016, INDIA \\ mustafa.ziaul@gmail.com
}

\begin{abstract}
In current times, emerging economies are providing digital services to its citizen through public or private organization. Literature indicates that digital services are facing major challenges with respect to its adoption among relevant users groups, largely due to the perceived risks surrounding digital services. A purposive sampling methodology was adopted for the empirical validation of the framework among user groups. With the use of Generalized Analytic Network Process (GANP), prioritization of different dimensions of risk has been illustrated. The result indicates that dimensions like privacy risk, performance risk and financial risk are the most important risk across digital services models. However physical risk, social risk, psychological risk and time risk are comparatively less important risk across digital services. This research also finds out that the end users are reluctant to provide their personal information. The sample size is relatively small which limits generalizability of results. However an application of GANP has been showcased for empirical research. The research outcome can help managers in deciding which dimensions of risk are more important for digital service delivery. This study focuses on the different facets of risk perceived by consumers towards the digital services available in smart cities. Perceived risk dimensions like privacy risk, performance risk, financial risk, physical risk, social risk, psychological risk and time risk, have shown that there is a need to prioritize these risk to the digital services which is offered to the residents of the smart cities.
\end{abstract}

Keywords: Information risk, Digital services, Smart cities, Perceived risk, Analytic Network Process, Emerging economies.

\section{Introduction}

The concept of "smart city" has emerged from the concept of "Intelligent Cities". The basic idea of smart cities is to use the existing resources in a "smarter" way. Smart cities provide ICTs infrastructure and digital services which poses risk while sharing information with the third party [57]. These risk can be classified as privacy, performance, financial, physical, social, psychological, and time risk [40]. Smart cities are 
sustainable, creative and livable cities. It is part of government vision for the development of urban habitats through smart cities. In order to develop smart cities, experts from various fields are needed such as consultants, marketing specialists, corporations and officials [54]. These entities should take an active role in provisioning and delivering the digital services which are used by the citizens of the smart cities. The concept of smart cities can be seen as an assemblage of Information and Communication Technologies (ICTs), cyber-physical systems, urban infrastructure, sustainable process and the practices which aims to increase the administrative efficiency, competitiveness and socio-economic inclusion [12,13]. A smart city needed to solve the issues such as ICTs and Digital services in order to improve the quality of life [57].

The world is moving towards the evolution of urbanization through smart cities. In order to make a smart city, various innovations related to information technology pose a threat to security and privacy. People in smart cities are already connected with various electronic gadgets such as mobile phones and laptops. The use of services are changing with new digital services introduced. In smart cities, many smart appliances, smart devices and smart energy meters have been used which makes the user reluctant to share the information through these digital services. As the number of digital services increases the risk associated with its use also increases [18]. Since 2011, the contribution to the smart cities has been critically scrutinized from different factors such as political economy, science and technology, ideological critiques and socioeconomical [54]. In general smart cities create a relation between the usages of technology in a socio-economical ecosystem. In our study, we are focusing on the management of risk in digital services, where literature is still at a nascent stage. Integration of digital services in smart cities lengthy, complex and often requires dispersed resources. There are few publications which indicates the Integration of IT services such as digital services in smart city system [46].

In this study, multi-dimensional nature of risk such as privacy risk, performance risk, financial risk, Physical risk, social risk, psychological risk and time risk has been explored in the context of digital services. Further the study highlights an application of an emerging methodology based on the Generalised Analytic Network Process (GANP) for empirical research for prioritization, which has not been explored till now [61].

This paper Evaluate the raking of the different dimensions of the risk while suing digital services. The organization of the paper are as follows. Section 2 provides a review of the study done on Perceived risk to evaluate the various consumer related services. Sections 3 describe the methodology used to prioritize and rank the multidimensions of perceived risk. This section also provides data analysis and interpretation, Cronbach's alpha, exploratory factor analysis, inter-item correlation matrix of variables. Further it provides the ranking of the dimension of the perceived risk. Section 4 discusses the findings of the research, Sections 5 concludes the paper. 


\section{$2 \quad$ Literature review}

A detailed review of literature has been conducted to understand the domain of risk in digital services better. With the increase in population of the urban area, the people are making strategies in order to improve the livings in urban areas. Further the use of digital services which makes the city to improve the existing information and communication technologies (ICTs). In subsequent sections, we first explore the literature surrounding smart cities, then explore the literature surrounding digital services and finally explore perceived risk [3] in such services.

\subsection{Smart Cities}

Smart city concept was introduced first in 1990s [4, 5, 16, 54]. There is no consistent definition of smart city till now which can fit the all the dimensions of smart city [4, $5,7,32,33,45,56]$. The concept of smart city has been explained as the utilization of human and technological capital for the development of urban agglomeration [5]. Various theoretical and managerial conceptualization has been introduced and the concepts of smart cities have gained the widest recognition among the urban researchers and the practitioners.

Major dimension of smart city are smart people, smart economy, smart mobility, smart living, smart governance and smart environment [4, 7, 12, 13, 32, 38, 57].

Digital services forms an integral part of smart cities, where residents are empowered to access these services using ICTs. Across all the dimensions of smart cities, digital services play an important role for the end consumers to realize the benefits envisioned from these smart cities.

\subsection{Digital Services}

There are various definitions of digital services in the literature $[6,10,27]$. The generic definition is "services or resources accessed and/or provided via digital transaction." [23]. With the use of digital services, the city will have a high quality of life which will lead to smart governance [33]. So the risk of sharing the personal information while using digital service make ends user afraid of data getting misused [29].

Digital services are accessed via internet with the use of an interactive software. It is generally referred as an information asset which is made available through internet. The most sought examples of digital services is online purchasing, banking and financial portfolio management. Digital services have been classified in literature based on the value they provide, their model of service delivery and parameters for assessment. For example, categorization of digital service as technology-assisted consumer contact, technology-facilitated consumer contact, technology-mediated consumer contact and technology generated consumer contact, based on the nature of interaction between the consumer, the service provider and technology [22]. The digital services may be categorised on the basis of delivery, maturity, malleability (provider and con- 
sumer of service), pricing and funding [59], which again strive to meet business, interaction and technological objectives. Again digital services classification done by the governments are often done on the nature of benefits. Across these digital services, it has been highlighted that adoption is significantly affected by the perception of risk in such services [20,35]; which is why a deeper exploration is required in the domain of risk in digital services.

\subsection{Risk in Digital Services}

Bauer has introduced the concept of risk and defined it as "a combination of uncertainty plus serious of outcome involved" whereas "the expectation of losses associated with the purchase and act as an inhibitor to purchase behavior" has been defined by [50] .Perceived risk is generally thought of as felt uncertainty with respect to the negative consequences of using a product or service [20].

The consumers are also very much sensitive about the privacy and security of the products or services which they purchase or consume through the internet $[8,12,53]$. The reason behind it was the fear of getting theft of the product or getting prersonal information misused by the company [19, 43, 44, 47]. The seven dimensions of perceived risk are as follows.

1. Privacy risk. The risk associated with the loss of personal information without your permission.

2. Performance risk. The possibility that the services or products is not delivering the desired benefits as it was advertised and designed.

3. Financial risk. The price associated with the purchase of products or services and the subsequent maintenance cost associated with it.

4. Physical risk. The risk associated with the safety of consumers while using product or services.

5. Social risk. The risk associated with the use of product or service leads to embarrassment in social media.

6. Psychological risk. The risk that using of the product or services will decrease the self-image of the consumer.

7. Time risk. The lost time associated with bad purchase decision such as researching and purchasing a product or services.

\section{$3 \quad$ Methodology}

Each dimensions of risk such as privacy risk, performance risk, financial risk, physical risk, social risk, psychological risk and time risk has been mapped to digital services. The data has been collected from the end users who are using digital services in two form: online and offline. The survey forms has been circulated to the end users of the smart cities. For proceeding with the analysis, data on preferences needed to be elicited through structured questionnaires from experienced user groups of the digital services residing in smart cities. The data was captured from the smart cities in the 
national capital region of India, where the access and usage of digital services by the residents was among the top three in the country. The targeted user groups had used at least two different models of digital services out of the four models of service delivery proposed by [22]. A purposive sampling methodology was adopted so that the elicited responses would have more richness and represent the concerns of user groups who are more frequent in using the digital services. Over 441 respondents were approached for administering the questionnaire through a combination of online and offline channels of communication. Out of this, only 100 respondent data could be collected which had the requisite degree of consistency, needed for the subsequent analysis.

During the review of literature, it has been seen that various authors have used different methodologies to evaluate perceived risk in different contexts. Data on preferences needed to be elicited through structured questionnaires from user groups of the digital services residing in smart cities. After the collection of data, analysis has be done using Generalized Analytic Network Process (GANP) proposed by [61] for prioritization of perceived risk dimension. This study also highlights the application of the GANP for prioritization of empirical data. It is an extension of Analytic Network Process (ANP) methodology which is used for Multi Criteria Decision Making (MCDM) to obtain the priorities of the compared element in a network hierarchy [52].

By using the GANP, this study further highlights how empirically prioritization of alternatives, which may not be free of exigencies and internal influences, may be done using this approach. While such empirical prioritization based on surveys on specific user groups has been done in past literature $[28,36]$ using the Analytic Hierarchy Process (AHP), no study has attempted to do the same using the GANP. The use of AHP becomes restricted when alternatives may also have an impact on one other and are not mutually independent. Hence the proposed approach also highlights the application of a new methodology in the context of risk assessment of digital services.

While following the approach of the GANP, first the Complex Comparison Matrix (CCM) is developed based on the judgment on 1-9 scale [28, 51]. The decision maker's judgment is crisp value which describes the relationship between paired comparisons. Among similar approaches, there are over 20 approaches for prioritization of preferences or judgments [30], however very few of these recent approaches have been used for empirical case studies.

\subsection{Data Analysis and Interpretation}

It has been noticed that end user are reluctant to provide their personal information [8, $12,53]$. In the survey, $97 \%$ respondent are male where as $3 \%$ are females. The total respondents' age group varies in such a way that it is $24 \%$ from $16-20$ years of age group, $53 \%$ from $21-25$ years of age group, $15 \%$ from $26-30$ years of age group, $4 \%$ from 31-35 years of age group and 2\% from 46-50 years of age group. The education qualification of the responds are such that $41 \%$ are having bachelor degree, $39 \%$ are having Master's degree, $8 \%$ are having doctorate degree and $12 \%$ have done higher secondary only. The employment status of the respondent are such that $10 \%$ belongs 
to under employment, $4 \%$ belongs to self-employed, $86 \%$ are still student. The employment types of the respondent are such that $20 \%$ are in Government sector, $4 \%$ are in private sector, $3 \%$ are having their own business and NGOs while $70 \%$ are unemployed. The average duration (in months) during which the respondent were using digital services is 51 months.

Reliability analysis was conducted using Cronbach's alpha to evaluate the value of all the variables and it is found to be 0.830 . The composite reliability and Cronbach's alpha values of 0.6 or greater are considered to the acceptable [25]. The values are as shown in the table 3.1.

Table 3.1. List of Variables

\begin{tabular}{|c|c|c|c|}
\hline $\begin{array}{l}\text { Risk Dimen- } \\
\text { sion }\end{array}$ & $\begin{array}{l}\text { Vari } \\
\text { able } \\
\text { ID }\end{array}$ & Risk Measurement indicators & $\begin{array}{l}\text { Cronbach } \\
\text { Alpha }\end{array}$ \\
\hline Privacy risk & $\mathrm{V}_{\mathrm{D}}$ & $\begin{array}{l}\text { What are the chances that your personal information } \\
\text { and privacy will get compromised? } \\
\text { What are the chances that the personal information } \\
\text { will be used while using digital service without your } \\
\text { knowledge? } \\
\text { If I use the digital service, hackers will take control of } \\
\text { my account. }\end{array}$ & 0.662 \\
\hline $\begin{array}{l}\text { Performance } \\
\text { risk }\end{array}$ & $\mathrm{V}_{\mathrm{A}}$ & $\begin{array}{l}\text { Services offered is not able to perform as designed } \\
\text { and creates problem for you. } \\
\text { Service Provider may not perform well and process } \\
\text { transactions correctly. }\end{array}$ & 0.603 \\
\hline Financial risk & $\begin{array}{l}V_{Q} \\
V_{R}\end{array}$ & $\begin{array}{l}\text { What are the chances that you will lose your money } \\
\text { by using these services? } \\
\text { Using banking services will lead to financial loss for } \\
\text { me. } \\
\text { Using the service subjects your bank account to fi- } \\
\text { nancial risk. }\end{array}$ & 0.760 \\
\hline Physical risk & $\begin{array}{l}\mathrm{V}_{\mathrm{K}} \\
\mathrm{V}_{\mathrm{L}} \\
\mathrm{V}_{\mathrm{M}} \\
\mathrm{V}_{\mathrm{N}} \\
\mathrm{V}_{\mathrm{O}}\end{array}$ & $\begin{array}{l}\text { Using these digital service poses a threat to my } \\
\text { health. } \\
\text { If you do NOT use service, you will live for a long } \\
\text { time. } \\
\text { If I use service, I will get ill. } \\
\text { If I use service, I will be exposed to harmful radia- } \\
\text { tion. } \\
\text { If I use this service, I will damage my brain. }\end{array}$ & 0.871 \\
\hline Social risk & $\mathrm{V}_{\mathrm{H}}$ & $\begin{array}{l}\text { What are the chances that others thinking will nega- } \\
\text { tively affect by using the services? } \\
\text { With the use of digital services, there will be social } \\
\text { loss for me because my relatives and friends will } \\
\text { think less highly of me. }\end{array}$ & 0.797 \\
\hline
\end{tabular}




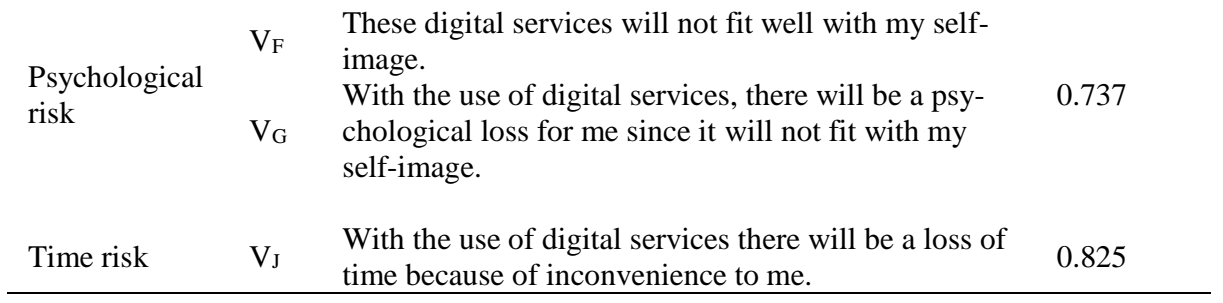

After aggregating all the normalized value from the end user, we get the final priority. Sub-dimension specific priority and dimension level priority, computed using the GANP as illustrated in table 3.2. It has been found that the privacy risk has first priority and time risk has the last priority. The priority of the risk are for the digital services from the end user perspective. The priority of the risk dimensions are illustrated in the table 3.2 .

Table 3.2. Priority of the different dimensions of Risk

\begin{tabular}{|c|c|c|c|c|}
\hline Priority of Variable & Priority Value & $\begin{array}{l}\text { Geometric } \\
\text { Mean }\end{array}$ & Type of Risk & Rank \\
\hline $\mathrm{V}_{\mathrm{D}}$ & 0.100899 & \multirow{3}{*}{0.096011} & \multirow{3}{*}{ Privacy Risk } & \multirow{3}{*}{1} \\
\hline $\mathrm{V}_{\mathrm{C}}$ & 0.095285 & & & \\
\hline $\mathrm{V}_{\mathrm{E}}$ & 0.092056 & & & \\
\hline $\mathrm{V}_{\mathrm{B}}$ & 0.065001 & \multirow{2}{*}{0.063244} & \multirow{2}{*}{ Performance Risk } & \multirow{2}{*}{2} \\
\hline $\mathrm{V}_{\mathrm{A}}$ & 0.061535 & & & \\
\hline $\mathrm{V}_{\mathrm{R}}$ & 0.062688 & \multirow{3}{*}{0.053748} & \multirow{3}{*}{ Financial Risk } & \multirow{3}{*}{3} \\
\hline$V_{P}$ & 0.061682 & & & \\
\hline $\mathrm{V}_{\mathrm{Q}}$ & 0.040156 & & & \\
\hline $\mathrm{V}_{\mathrm{K}}$ & 0.058852 & \multirow{5}{*}{0.043965} & \multirow{5}{*}{ Physical Risk } & \multirow{5}{*}{4} \\
\hline $\mathrm{V}_{\mathrm{N}}$ & 0.050532 & & & \\
\hline $\mathrm{V}_{\mathrm{L}}$ & 0.044987 & & & \\
\hline $\mathrm{V}_{\mathrm{M}}$ & 0.029691 & & & \\
\hline $\mathrm{V}_{\mathrm{O}}$ & 0.04135 & & & \\
\hline $\mathrm{V}_{\mathrm{H}}$ & 0.043696 & \multirow{2}{*}{0.040426} & \multirow{2}{*}{ Social Risk } & \multirow{2}{*}{5} \\
\hline $\mathrm{V}_{\mathrm{I}}$ & 0.037401 & & & \\
\hline $\mathrm{V}_{\mathrm{F}}$ & 0.040694 & \multirow{2}{*}{0.038126} & \multirow{2}{*}{ Psychological Risk } & \multirow[b]{2}{*}{6} \\
\hline $\mathrm{V}_{\mathrm{G}}$ & 0.035721 & & & \\
\hline $\mathrm{V}_{\mathrm{J}}$ & 0.037773 & 0.037773 & Time Risk & 7 \\
\hline
\end{tabular}




\section{Discussion}

Previous research has focused on the different dimension of the risk for the adoption of e-services such as given by [14] has focused on the financial risk, social risk, privacy risk, and psychological risk for the adoption of technology has focused on the financial risk, psychological risk, privacy risk, time risk, performance risk, and overall risk in order to evaluate the adoption of e-services [20]. The study by [3] has taken financial risk, privacy risk, psychological risk, and performance risk dimensions of the perceived risk to illustrate how adoption of mobile banking influence the consumer.

In a study done by [11], privacy risk, source risk and performance risk were are first, second and third most important dimensions of risk while time risk, financial risk and social risk were the sixth, seventh and eight position in in the raking of all the eight dimensions of risk. In contract to our findings says that privacy risk, performance risk and financial risk are the first, second and third most important dimensions of perceived risk as shown in table 3.2. In a study done by [35], it shows that the security, time, financial, social, and performance risk negatively affects the adoption of online banking services. It also shows that security, financial and performance risk are the top most important risk factor where as social and time risk are fourth and fifth most important risk. The study has taken only four dimensions of the perceived risk and concluded that performance risk are the most important risk dimensions followed by financial risk, psychological risk and time risk during internet shopping [21].

A closer look into the prioritization of risks highlight that dominant cluster of risk would include privacy risk, performance risk and financial risk. This is a contrasting finding from that of previous literature [20] who highlighted that the dominant risks affecting adoption are time risk, psychological risk, privacy risk and financial risk. Probably due to the maturity of technology and processes, the aspect of time risk is lowered in the recent times. Connecting our findings to adoption related literature [35] it is understandable that privacy risk and financial risk affects the perceived usefulness of any digital service, while social risks affect social norms. However privacy risk, time risks and financial risks affect intention for adoption of digital services. It appears that our findings highlight that performance risk becomes a perceived usefulness which again drives adoption. The impact of social risks (and probably social norms) is noticeable in our findings. Hence it is possible that user groups is gradually losing its significance as more and more users of digital services are viewing it as a necessity due to its high utility rather than an alternative, and hence are less affected by social norms [39].

\section{Conclusion}

The output of the research can be useful for the policy makers, consultants, big enterprises and entrepreneurs in making the strategic, tactical and operational decisions. The research outcome can help managers in deciding which dimensions of risk are more important for digital service delivery. Also how different dimensions of risk 
affects consumption of digital services and affect failures will be provided, which will impact policies surrounding service management.

Further this study highlights how empirically prioritization of alternatives, which may not be free of exigencies and internal influences, may be done using the GANP. While such prioritization has been done in past literature using the Analytic Hierarchy Process $[28,36]$, no study has attempted to do the same using the GANP, since this methodological development is rather recent. Hence the proposed approach also highlights the application of a new methodology in the context of risk assessment of digital services. This approach may be adopted in future research for other prioritization problems when responses are elicited from user groups or experts and findings are validated empirically.

\section{References}

1. Agarwal, S., Teas, K.R.: Perceived value: Mediating role of perceived risk. J. Mark. Theory Pract. 9, 4, 1-14 (2001).

2. Agarwal, S., Teas, R.K.: Cross-national applicability of a perceived risk-value model. J. Prod. Brand Manag. 13, 4, 242-256 (2004).

3. Alalwan, A.A. et al.: Consumer adoption of mobile banking in Jordan Examining the role of usefulness, ease of use, perceived risk and self-efficacy. J. Enterp. Inf. Manag. 29, 1, 118-139 (2016).

4. Albino, V. et al.: Smart Cities : Definitions, Dimensions, Performance, and Initiatives. J. Urban Technol. 22, 1, 3-21 (2015).

5. Angelidou, M.: Smart cities : A conjuncture of four forces. Cities. 47, 95-106 (2015).

6. Barrett, M. et al.: Service Innovation in the digital age: Key contributions and future directions. MIS Q. 39, 1, 135-154 (2015).

7. Batty, M. et al.: Smart cities of the future. Eur. Phys. J. Spec. Top. 214, 1, 481-518 (2012).

8. Belanche-Gracia, D. et al.: Determinants of multi-service smartcard success for smart cities development: A study based on citizens' privacy and security perceptions. Gov. Inf. Q. 32, 2, 154-163 (2015).

9. Bettman, J.R.: Perceived Risk and Its Components: A Model and Emperical Test. J. Mark. Res. 10, 2, 184-190 (1973).

10. Buchanan, S., McMenemy, D.: Digital service analysis and design: The role of process modelling. Int. J. Inf. Manage. 32, 3, 251-256 (2012).

11. Cases, A.-S.: Perceived risk and risk-reduction strategies in Internet shopping. Int. Rev. Retail. Distrib. Consum. Res. 12, 4, 375-394 (2002).

12. Chatterjee, S., Kar, A.K.: Smart Cities in Developing Economies: A Literature Review and Policy Insights. In: International Conference onAdvances in Computing, Communications and Informatics. pp. 2335-2340 (2015). 
13. Chauhan, $\mathrm{S}$. et al.: Addressing big data challenges in smart cities: a systematic literature review"Addressing big data challenges in smart cities: a systematic literature review.” info. 18, 4, 73-90 (2016).

14. Cocosila, M. et al.: Early investigation of new information technology acceptance: A perceived risk - Motivation model. Commun. Assoc. Inf. Syst. 25, 1, 339-358 (2009).

15. Cox, D.F., Rich, S.U.: Perceived Risk and Consumer Decision-Making: The Case of Telephone Shopping. J. Mark. Res. 1, 4, 32-39 (1964).

16. Crivello, S.: Urban Policy Mobilities: The Case of Turin as a Smart City. Eur. Plan. Stud. 23, 5, 909-921 (2015).

17. Dowling, G.R., Staelin, R.: A Model of Perceived Risk and Intended Riskhandling Activity. J. Consum. Res. 21, 1, 119-134 (1994).

18. Elmaghraby, A.S., Losavio, M.M.: Cyber security challenges in smart cities: Safety, security and privacy. J. Adv. Res. 5, 4, 491-497 (2014).

19. Featherman, M.S. et al.: Reducing online privacy risk to facilitate e-service adoption: the influence of perceived ease of use and corporate credibility. J. Serv. Mark. 24, 3, 219-229 (2010).

20. Featherman, M.S., Pavlou, P.A.: Predicting e-services adoption: a perceived risk facets perspective. Int. J. Hum. Comput. Stud. 59, 4, 451-474 (2003).

21. Forsythe, S.M., Shi, B.: Consumer patronage and risk perceptions in Internet shopping. J. Bus. Res. 56, 867-875 (2003).

22. Froehle, C.M., Roth, A. V.: New measurement scales for evaluating perceptions of the technology-mediated customer service experience. J. Oper. Manag. 22, 1, 1-21 (2004).

23. Fung, W. et al.: Hedge Funds: Performance, Risk, and Capital Formation. J. Finance. 63, 4, 1777-1803 (2008).

24. Gefen, D. et al:: A Research Agenda for Trust in Online Environments. J. Manag. Inf. Syst. 24, 4, 275-286 (2008).

25. Gefen, D. et al.: Structural Equation Modeling and Regression: Guidelines for Research Practice. Commun. Assoc. Inf. Syst. 4, October, 1-77 (2000).

26. Grewal, D. et al.: The Moderating Effects of Message Framing and Source Credibility on the Price-perceived Risk Relationship. J. Consum. Res. 21, 1, 145-153 (1994).

27. Higgs, G. et al.: Investigating variations in the provision of digital services in public libraries using network-based GIS models. Libr. Inf. Sci. Res. 35, 1, 24-32 (2013).

28. Kar, A.K., Pani, A.K.: Exploring the importance of different supplier selection criteria. Manag. Res. Rev. 37, 1, 89-105 (2014).

29. Kerviler, G. De et al.: Adoption of in-store mobile payment: Are perceived risk and convenience the only drivers? J. Retail. Consum. Serv. 31, 334-344 
(2016)

30. Khatwani, G., Kar, A.K.: Improving the Cosine Consistency Index for the analytic hierarchy process for solving multi-criteria decision making problems. Appl. Comput. Informatics. in press, 2016, (in press) (2016).

31. Kourtit, K. et al.: A multi-actor multi-criteria analysis of the performance of global cities. Appl. Geogr. 49, 24-36 (2014).

32. Lazaroiu, G.C., Roscia, M.: Definition methodology for the smart cities model. Energy. 47, 1, 326-332 (2012).

33. Lee, J.H. et al.: An integrated service-device-technology roadmap for smart city development. Technol. Forecast. Soc. Chang. 80, 2, 286-306 (2013).

34. Lee, J.J. et al.: A Broader View of Perceived Risk during Internet Transactions. Commun. Assoc. Inf. Syst. 38, 171-189 (2016).

35. Lee, M.: Factors influencing the adoption of internet banking: An integration of TAM and TPB with perceived risk and perceived benefit. Electron. Commer. Res. Appl. 8, 130-141 (2009).

36. Lee, Y., Kozar, K.A.: Investigating the effect of website quality on e-business success: An analytic hierarchy process (AHP) approach. Decis. Support Syst. 42, 1383-1401 (2006).

37. Lim, N.: Consumers' perceived risk: Sources versus consequences. Electron. Commer. Res. Appl. 2, 3, 216-228 (2003).

38. Lombardi, P. et al.: Modelling the smart city performance. Innov. Eur. J. Soc. Sci. Res. 25, 2, 137-149 (2012).

39. Lu, J.: Personal Innovativeness, Social Influences and Adoption of Wireless Internet Services via Mobile Technology. J. Strateg. Inf. Syst. 14, 245-268 (2005).

40. Luo, X. et al.: Examining multi-dimensional trust and multi-faceted risk in initial acceptance of emerging technologies: An empirical study of mobile banking services. Decis. Support Syst. 49, 2, 222-234 (2010).

41. Mardani, A. et al.: Multiple criteria decision-making techniques and their applications - a review of the literature from 2000 to 2014. Econ. Res. Istraživanja. 28, 1, 516-571 (2015).

42. Mitra, K. et al.: An examination of perceived risk, information search and behavioral intentions in search, experience and credence services. J. Serv. Mark. 13, 3, 208-228 (1999).

43. Mohd Nishat, F. et al.: Information risks management in supply chains: an assessment and mitigation framework. J. Enterp. Inf. Manag. 20, 6, 677-699 (2007).

44. Nazimoglu, Ö., Özsen, Y.: Analysis of risk dynamics in information technology service delivery. J. Enterp. Inf. Manag. 23, 3, 350-364 (2010).

45. Neirotti, P. et al.: Current trends in smart city initiatives: Some stylised facts. 
Cities. 38, 25-36 (2014).

46. Orlowski, S., Orlowski, S.: Government initiatives in information technology security Government initiatives in information technology security. Inf. Manag. Comput. Secur. 5, 3, 111-18 (1997).

47. Özkan, S. et al.: Facilitating the adoption of e-payment systems: theoretical constructs and empirical analysis. J. Enterp. Inf. Manag. 23, 3, 305-325 (2010).

48. Paroutis, S. et al.: A strategic view on smart city technology: The case of IBM Smarter Cities during a recession. Technol. Forecast. Soc. Chang. 89, 262272 (2014).

49. Pazalos, K. et al.: A structured methodology for assessing and improving eservices in digital cities. Telemat. Informatics. 29, 1, 123-136 (2012).

50. Peter, J.P., Ryan, M.J.: An Investigation of Perceived Risk at the Brand Level. J. Mark. Res. 13, 2, 184-188 (1976).

51. Saaty, R.W.: The analytic hierarchy process-what it is and how it is used. Math. Model. 9, 3-5, 161-176 (1987).

52. Saaty, T.L., Vargas, L.G.: The Analytic Network Process. Decis. Mak. with Anal. Netw. Process. 195, 1-40 (2013).

53. Singhal, H., Kar, A.K.: Information Security Concerns in Digital Services: Literature Review and a Multi-Stakeholder Approach. In: International Conference on Advances in Computing, Communications and Informatics. pp. 901-906 (2015).

54. Söderström, O. et al.: Smart cities as corporate storytelling. City. 18, 3, 307320 (2014).

55. Steelman, Z.R. et al.: Data collection in digital age: innovative alternatives to student samples. MIS Q. 38, 2, 355-378 (2014).

56. Steenbruggen, J. et al.: Data from mobile phone operators: A tool for smarter cities? Telecomm. Policy. 39, 335-346 (2015).

57. Tachizawa, E.M. et al.: How "smart cities" will change supply chain management. Supply Chain Manag. An Int. J. 20, 3, 237-248 (2015).

58. Wang, J. et al.: A value-at-risk approach to information security investment. Inf. Syst. Res. 19, 1, 106-120 (2008).

59. Williams, K. et al.: Design of emerging digital services: a taxonomy. Eur. J. Inf. Syst. 17, 5, 505-517 (2008).

60. Yadav, S.B., Dong, T.: A comprehensive method to assess work system security risk. Commun. Assoc. Inf. Syst. 34, 1, 169-198 (2014).

61. Zhu, B. et al.: Generalized analytic network process. Eur. J. Oper. Res. 244, 1, 277-288 (2015). 